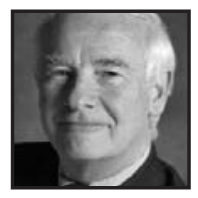

\title{
Blueprint for a Smart Nation
}

\author{
David Johnston, University of Waterloo
}

\section{ABSTRACT}

Canada is in desperate need of a national strategy that harnesses education and innovation to address the intellectual health of the nation, just as the Canada Health Act was created to protect and enhance the physical well-being of Canadians. A Canada Learning and Innovation Act (the "Smart Nation Act") would help close the longstanding productivity gap that exists between Canada and its peers, and reverse the decline in research and development investments. The Act will recognize the importance of lifelong learning, the need to invest in knowledge and talented people, and the opportunities for collaboration that will bring about new innovations.

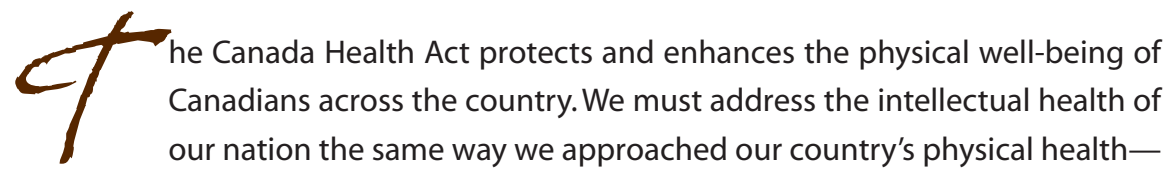
by building a national framework to secure the well-being of our nation's most valuable resource, its talented people.

Other nations have recognized that national strategies for education and innovation are key. In the United States, for example, the Higher Education Act was a critical component to President Lyndon Johnson's "Great Society" agenda in the 1960s.

Canada is in desperate need of a national strategy that combines education and innovation. Our productivity levels remain stagnant when compared to our peers. According to the Council of Canadian Academies (2009), Canada's business sector productivity has fallen from 90 per cent of the U.S. level in 1984 to 76 per cent in 
2006 (p. 5). International innovation success stories are in short supply, BlackBerries notwithstanding.

Currently, Canada is not investing enough in research and development. Research and development expenditures account for 1.9 per cent of Canada's Gross Domestic Product (GDP), an amount below the Organization for Economic Co-operation and Development's (OECD) average of 2.2 per cent. The Council of Canadian Academies reports that business research and development (R\&D) as a percentage of GDP has fallen by 20 per cent between 2001 and 2007.

Canada also lags its OECD peers in the production of advanced degrees. For example, in the province of Ontario, less than one Master's degree was granted per 1,000 people in 2006, compared to 2.01 per 1,000 people in the United States; for $\mathrm{PhDs}$, the figure is 0.14 per 1,000 people in Ontario, versus 0.19 per 1,000 in the U.S. (Task Force on Competitiveness, Productivity and Economic Progress, 2009, p. 45). The Science, Technology and Innovation Research Council (2009) reports that Canada ranks $21^{\text {st }}$ in the OECD for production of science and engineering degrees (p. 54).

That is why I have proposed the Canada Learning and Innovation Act ("the Smart Nation Act"). If Canada wants to be a truly smart nation, it will invest in people, their ideas, and the application of those ideas through its commitment to learning on a national level.

The Act is anchored in three core premises. The first premise is that the opportunity to learn, to develop intellectually, to improve skills capability and to achieve one's best is the right of each Canadian at any age. The second premise is that the best path to creating a civic and prosperous society is through embracing lifelong learning and innovation. The third premise is that knowledge and its innovative application is a national treasure best fostered by engaging every citizen in its pursuit, but anchored by ambitious investments in research and development.

The objectives of the Act are far reaching. The Act will seek to make appropriate learning opportunities available to all Canadians at every stage of life, beginning from the earliest years and at every place in the country. It will ensure opportunities to create and disseminate knowledge through research and development equal to the best in the world. The Act will seek to meet the highest learning and innovation standards worldwide. The Act will maintain and create techniques and avenues to ensure affordable learning opportunities with due regard for the individual's responsibility to contribute to or repay the collective investment made. It will 
also recognize that different persons learn best in different ways and will emphasize techniques to reach out in innovative ways to attract individuals to learn to the best of their capabilities.

The Act will recognize the importance of lifelong learning by establishing goals to maximize such opportunities for all Canadians. It will also recognize the overriding social and economic significance of investment in knowledge and in skilled and learned people by establishing goals for investment. Also, the Act will endeavour to build Canada's capacity for research and development and to generate knowledge. The receptor capacity to apply knowledge will use comparative measures for "best in the world" practices to measure progress. For research and development, this will include measures of investment at levels comparable to the best in the world. For learning opportunities, this will include measures to ensure breadth and depth of such opportunities and comparison with the best in the world by helping to develop the maximum capabilities of all individuals.

Sociologists Fred Block and Matthew Keller conducted a review of awardwinning innovations in the United States between 1971 and 2006 and concluded that groundbreaking innovations have increasingly resulted from partnerships among government, business and academia, rather than from companies acting on their own. In 1971, 86 per cent of the top innovations were developed privately, but by 2006, that number had fallen to 31 per cent (Block \& Keller, 2008, p. 10).

The Act will invest resources where they will do the most good-funding research and teaching activities that will not only develop new technologies for a new economy, but also prepare talented people to make the most of those innovations. Building Canada's research and development ecosystem must be done systematically as part of a larger effort to create a truly smart nation.

The Act will craft accountability principles to measure and enhance the efficiency and effectiveness of investment in learning and innovation systems and institutions that can be benchmarked against the best in the world. These should include, first, secondary school graduation achievement for at least 90 per cent of Canada's youth and tracked programs to age 21 for the remaining 10 per cent, and, second, robust standards for trade certification, college diploma, undergraduate and graduate degrees.

The Act will also recognize that education is a wonderful export industry: it is environmentally clean and value-added. A recent study submitted to the 
Department of Foreign Affairs and Trade shows the economic impact of international education in Canada. The authors of this report found that in 2008, Canada's 178,227 international students, studying at universities and colleges, spent $\$ 6.25$ billion on tuition, accommodation and discretionary spending (Roslyn Kunin \& Associates, Inc., 2009 , p. 33). To put that in perspective, the total amount that international students spend in Canada is greater than our country's export of coniferous lumber at \$5.1 billion annually. International students generated \$291 million in government revenue, and international education services contribute 65,000 jobs to the labour market across Canada, or 5.5\% of the total jobs in Canada's education services sector (p. 34).

Canada is poised to share its learning and innovation experience with citizens in other parts of the world. Therefore, the Act will include measures to harmonize Canada's immigration and visa policies to attract talented people from elsewhere, measures to help foreign-trained individuals bridge their skills appropriately with the Canadian workplace, opportunities for international students to apply for landed immigrant status while studying in Canada, recognition of international credentials comparable to the best in the world, efforts to encourage Canadian students to study and work abroad to cultivate truly global citizens, efforts to export our learning and innovation systems and opportunities and share Canadian expertise with the world, and incentives to encourage Canadians to both work and learn past the traditional retirement age.

The goal is to make appropriate learning opportunities available to Canadians of all ages, regardless of their geographical location. At the same time, it will meet the highest world standards of learning and innovation, and will ensure that those standards become the floor and not the ceiling of our national learning ambitions. Developing the skills, talent, and innovation capacity, both of individual Canadians and the country as a whole, is the best way to promote long-term, sustainable economic prosperity. Our intellectual health as a nation must be a national priority.

\section{References}

Block, F., \& Keller, M. (2008). Where do innovations come from? Transformations in the U.S. national innovation system, 1970-2006. The Information Technology and Innovation Foundation. Retrieved April 13, 2010, from http://archive.itif.org/index.php?id=158
Council of Canadian Academies (2009). Innovation and business strategy: Why Canada falls short. Retrieved April 13,2010, from http://www.scienceadvice.ca/uploads /eng/assessments\%20and\%20publications $\% 20$ and\%20news\%20releases/inno/\%28 2009-06-11\%29\%20innovation \%20 report.pdf 
Roslyn Kunin and Associates, Inc. (2009). Economic impact of international education in Canada. Retrieved April 13, 2010, from http://www.international.gc.ca/edu cation/assets/pdfs/RKA_IntEd_Report_en g.pdf

Science, Technology and Innovation Research Council (2009). State of the nation 2008: Canada's science, technology and innovation system. Government of Canada. Retrieved April 13, 2010, from http://www.stic-csti.ca/eic/site/sticcsti.nsf/eng/h_00011.html
Task Force on Competitiveness, Productivity and Economic Progress (2009). Navigating through the recovery. Institute for Competitiveness and Prosperity. Retrieved April 13, 2010, from http://www.competeprosper.ca/index.php/work/annual_ reports/annual_report_8/

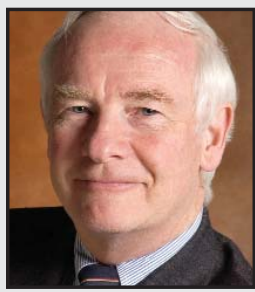

David Johnston has been President of the University of Waterloo since June 1999. He was previously Principal of McGill University, Dean of the Law Faculty at the University of Western Ontario, and a faculty member at the University of Toronto. His academic specializations are securities regulation, corporation and information technology law. Among many honours accorded Professor Johnston are honorary doctorates from thirteen universities and Companion of the Order of Canada. He is the author/co-author of numerous books, including Getting Canada Online: Understanding the Information Highway, which is intended to challenge Canadians to use the information revolution to build a more economically competitive and civic society, as well as Cyberlaw, Communications Law and most recently, Canadian Securities Regulation, $5^{\text {th }}$ edition. He has served on many provincial and federal task forces and committees and is on the boards of a number of companies and foundations.

LINK TO:

www.uwaterloo.ca 